\title{
Chorioamnionitis: Important Risk Factor or Innocent Bystander for Neonatal Outcome?
}

\author{
Wolfgang Thomas Christian P. Speer \\ University Children's Hospital Würzburg, Würzburg, Germany
}

\section{Key Words}

Antenatal infection - Prematurity - Bronchopulmonary dysplasia - Respiratory distress syndrome - Cerebral palsy • White matter disease $\cdot$ Periventricular leukomalacia $\cdot$ Small for gestational age $\cdot$ Antenatal steroids

\begin{abstract}
Chorioamnionitis as a major risk factor for spontaneous preterm birth, especially at earlier gestational ages, contributes to prematurity-associated mortality and morbidity. A gestation-independent effect of chorioamnionitis on neonatal outcome is much more difficult to assess. The influence of chorioamnionitis on neonatal outcome has become less evident with advances in neonatal care. A short-term beneficial effect of histological, but not clinical chorioamnionitis on incidence and severity of respiratory distress syndrome in preterm infants is evident. This maturational effect is accompanied by a susceptibility of the lung for further postnatal injury, which predisposes for bronchopulmonary dysplasia. Chorioamnionitis is associated with cystic periventricular leukomalacia, intraventricular hemorrhage and cerebral palsy in preterm infants, but its association with noncystic white matter disease is not clear yet. Prenatal inflammation/infection has been shown a risk factor for neonatal sepsis. A single course of antenatal steroids can be regarded safe in clinical as well as histological chorioamnionitis.
\end{abstract}

Copyright $\odot 2010$ S. Karger AG, Basel

\section{KARGER}

Fax +41613061234 E-Mail karger@karger.ch www.karger.com
(C) 2010 S. Karger AG, Basel

1661-7800/11/0993-0177\$38.00/0

Accessible online at:

www.karger.com/neo

\section{Chorioamnionitis}

The term chorioamnionitis is used to describe an intrauterine status of inflammation in tissues of either mixed fetal-maternal (choriodecidual space) or fetal origin (chorioamniotic membranes, amniotic fluid and umbilical cord) [1]. Histological chorioamnionitis is accompanied by evidence for invasion of pathogens in normally sterile tissues in most cases [2, 3]. Apart from histological signs (infiltration of polymorphonuclear cells), microbiological (positive culture/polymerase chain reaction for pathogens) and biochemical (elevated intraamniotic cytokines) criteria are often used to define chorioamnionitis [4-6]. Most pathogens associated with chorioamnionitis are of low virulence and the inflammatory process in most cases is a subclinical condition. Clinical chorioamnionitis, variably defined by the presence of maternal fever, tachycardia, leukocytosis or elevated C-reactive protein, uterine tenderness, foul-smelling vaginal discharge or fetal tachycardia, is present only in a minority of cases with either histologically, microbiologically or biochemically proven chorioamnionitis (fig. 1) [1, 7-9].

The fetal inflammatory response syndrome (FIRS) is characterized by activation of the innate immune system of the fetus exposed to infection/inflammation in utero [10]. FIRS was originally defined on the basis of increased cord blood concentrations of interleukin (IL)-6 which

Dr. Wolfgang Thomas

University Children's Hospital

Josef-Schneider-Strasse 2, DE-97080 Würzburg (Germany)

Tel. +49931 2012 7274, Fax +4993120127833

E-Mail thomas_w@kinderklinik.uni-wuerzburg.de 
Fig. 1. Schematic illustration of different approaches to define chorioamnionitis and their interrelationship. The most sensitive method to define chorioamnionitis is by histological examination. Clinical signs of chorioamnionitis will be found in a minority of cases with 'microbiological', 'biochemical' or 'histological' chorioamnionitis. An inflammatory response of the fetus is reflected by elevated blood cytokines or vasculitis of the umbilical cord/chorionic plate.

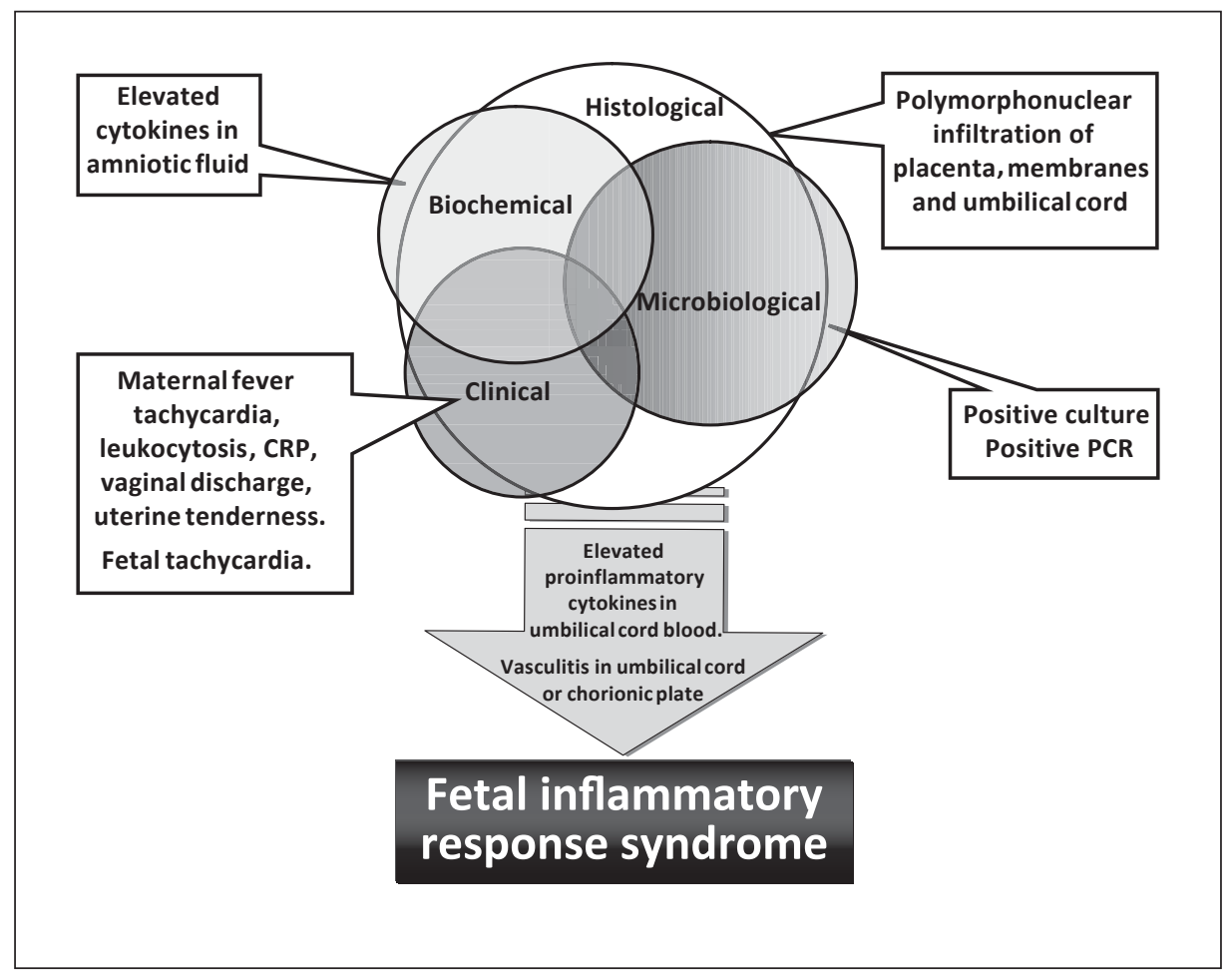

was shown associated with adverse neonatal outcome [11]. Meanwhile, many other soluble blood markers for FIRS, mainly proinflammatory cytokines like IL- $1 \beta$ and tumor necrosis factor- $\alpha$ (TNF- $\alpha$ ), have been introduced [10] and histological funisitis/chorionic vasculitis has been suggested as the histological counterpart of FIRS.

\section{Chorioamnionitis and Preterm Birth}

In the last decades, advances in perinatology and neonatology have led to a considerable amelioration of neonatal outcome after preterm birth. Meanwhile, the world's birth rate of preterm infants has been consistently rising with prematurity being the most important risk factor for death before the first birthday in high-income countries [12]. Most recently, data from a multicenter study, including more than 1,200 infants born before 28 weeks of gestational age, have clearly underlined the close relationship of microbial colonization of placental tissue as well as histological evidence for placental and umbilical cord vessel inflammation with spontaneous early preterm birth $[13,14]$. According to microbiological data, at least every fourth preterm birth is supposed to be caused by intrauterine bacterial infection [12]. An ethnic predisposition for histological chorioamnionitis, which cannot be explained completely by different utilization of prenatal healthcare and lifestyles [15], seems to contribute to the higher prevalence of preterm deliveries among AfricanAmerican women [16]. The recovery rate of microorganisms with culture techniques both from amniotic fluid and from placental tissues decreases significantly with increasing gestational age in women presenting with preterm labor [17, 18]. Reported colonization rates have been as high as $79 \%$ for births at 23 weeks of gestational age in this group [18]. Elevated concentrations of proinflammatory cy tokines in amniotic fluid have been shown associated with delivery at lower gestational ages after preterm labor, which suggests that intrauterine infection triggers preterm birth via mechanisms involving local cytokine production $[19,20]$. Intraamniotic IL-6 concentrations have been identified as a more valuable predictor of preterm birth than positive amniotic fluid culture results [21]. However, this does not inevitably mean that intrauterine inflammation is often present in the absence of infection. It rather reflects the inadequacy of amniotic fluid cultures to detect pathogens like Ureaplasma compared to newer techniques like polymerase chain reaction 
Table 1. Studies assessing the association of histological chorioamnionitis with RDS and BPD

\begin{tabular}{|c|c|c|c|c|c|c|}
\hline \multirow[t]{2}{*}{ Reference (first author) } & \multirow[t]{2}{*}{ Cohort } & \multirow[t]{2}{*}{ Study type } & \multirow[t]{2}{*}{ Group size } & \multirow[t]{2}{*}{ Study period } & \multicolumn{2}{|c|}{ Outcome } \\
\hline & & & & & RDS & $\mathrm{BPD}$ \\
\hline Watterberg, 1996 [36] & $\begin{array}{l}<2,000 \mathrm{~g} \\
\mathrm{n}=53\end{array}$ & $\begin{array}{l}\text { prospective } \\
\text { single-center }\end{array}$ & $36 \mathrm{CA}+$ & 1987-1989 & $\downarrow$ & $\uparrow^{\mathrm{a}}$ \\
\hline Redline, 2002 [34] & $\begin{array}{l}<32 \text { weeks' GA } \\
<1,500 \mathrm{~g}, \mathrm{n}=371\end{array}$ & $\begin{array}{l}\text { retrospective } \\
\text { single-center }\end{array}$ & $\begin{array}{l}169 \mathrm{CA}+ \\
\mathrm{CA}+, \mathrm{CPV}+\end{array}$ & 1995-1997 & $\begin{array}{l}\text { n.a. } \\
\text { n.a. }\end{array}$ & $\vec{\rightarrow}$ \\
\hline Van Marter, 2002 [35] & $\mathrm{BW}<1,500 \mathrm{~g}$ & $\begin{array}{l}\text { retrospective multicenter } \\
\text { case-control }^{c}\end{array}$ & $146 \mathrm{CA}+$ & 1991-1993 & n.a. & $\begin{array}{l}\downarrow^{b} \\
\uparrow^{d}\end{array}$ \\
\hline Ogunyemi, 2003 [39] & $\begin{array}{l}<32 \text { weeks' GA } \\
\mathrm{n}=774\end{array}$ & $\begin{array}{l}\text { retrospective } \\
\text { single-center }\end{array}$ & $254 \mathrm{CA}+$ & 1992-2000 & $\rightarrow$ & $\uparrow$ \\
\hline Kent, 2004 [29] & $\begin{array}{l}<30 \text { weeks' GA } \\
\mathrm{n}=241\end{array}$ & $\begin{array}{l}\text { prospective } \\
\text { single-center }\end{array}$ & $\begin{array}{l}40 \mathrm{CA}+\mathrm{F}- \\
40 \mathrm{CA}+\mathrm{F}+\end{array}$ & 1996-2001 & $\begin{array}{l}\text { n.a. } \\
\text { n.a. }\end{array}$ & $\begin{array}{l}\rightarrow \\
\rightarrow\end{array}$ \\
\hline Richardson, 2006 [49] & $\begin{array}{l}25-34 \text { weeks' GA } \\
\mathrm{n}=606\end{array}$ & $\begin{array}{l}\text { retrospective } \\
\text { single-center }\end{array}$ & $\begin{array}{l}114 \mathrm{CA}+\mathrm{F}- \\
178 \mathrm{CA}+\mathrm{F}+\end{array}$ & 1995-2003 & $\begin{array}{l}\rightarrow \\
\rightarrow\end{array}$ & $\begin{array}{l}\rightarrow \\
\rightarrow\end{array}$ \\
\hline Zanardo, 2008 [38] & $\begin{array}{l}<32 \text { weeks' GA } \\
\mathrm{n}=287\end{array}$ & $\begin{array}{l}\text { prospective } \\
\text { single-center }\end{array}$ & $68 \mathrm{CA}+$ & 2001-2006 & $\rightarrow$ & $\uparrow$ \\
\hline Kaukola, 2009 [28] & $\begin{array}{l}<32 \text { weeks' GA } \\
\mathrm{n}=163\end{array}$ & $\begin{array}{l}\text { prospective } \\
\text { single-center }\end{array}$ & $64 \mathrm{CA}+$ & 1998-2002 & $\downarrow$ & $\rightarrow$ \\
\hline Lahra, 2009 [30] & $\begin{array}{l}<30 \text { weeks' GA } \\
\mathrm{n}=724\end{array}$ & $\begin{array}{l}\text { retrospective } \\
\text { single-center }\end{array}$ & $\begin{array}{l}138 \mathrm{CA}+\mathrm{F}- \\
219 \mathrm{CA}+\mathrm{F}+\end{array}$ & 1992-2001 & $\begin{array}{l}\downarrow \\
\downarrow\end{array}$ & $\begin{array}{l}\text { n.a. } \\
\text { n.a. }\end{array}$ \\
\hline Lahra, 2009 [31] & $\begin{array}{l}<30 \text { weeks' GA } \\
\mathrm{n}=761\end{array}$ & $\begin{array}{l}\text { retrospective } \\
\text { single-center }\end{array}$ & $\begin{array}{l}140 \mathrm{CA}+\mathrm{F}- \\
208 \mathrm{CA}+\mathrm{F}+\end{array}$ & 1992-2004 & $\begin{array}{l}\text { n.a } \\
\text { n.a. }\end{array}$ & $\vec{\downarrow}$ \\
\hline
\end{tabular}

$\mathrm{GA}=$ Gestational age; $\mathrm{CA}=$ histological chorioamnionitis; $\mathrm{F}=$ histological funisitis/umbilical cord vasculitis; $\mathrm{CPV}=$ chorionic plate vasculitis; n.a. = data not available.

${ }^{a}$ Defined as need for supplemental oxygen on day 30 of life. ${ }^{b}$ If mechanically ventilated $<7$ days. ${ }^{c}$ Infants with and without BPD were matched. ${ }^{\mathrm{d}}$ If mechanically ventilated $\geq 7$ days or postnatal sepsis.

[22]. Physiological labor at term is also characterized by histological chorioamnionitis in a considerable number of cases and by elevated intraamniotic proinflammatory cytokine levels, underlining the crucial role of inflammation in normal parturition [23].

To conclude, there is unequivocal evidence that chorioamnionitis - either defined clinically, histologically, microbiologically or biochemically - is a major risk factor for spontaneous preterm birth [24]. It therefore contributes to the high morbidity and mortality of infants born prematurely [1].

\section{Chorioamnionitis as Gestation-Independent Risk Factor for Neonatal Outcome - Methodological Pitfalls}

There is still controversy if gestation-independent effects of chorioamnionitis on neonatal outcome exist [6]. Some cohort studies addressing this issue might simply not have the power to identify gestational age as a confounder or risk modifier. Besides, reported associations between chorioamnionitis and adverse outcome in preterm and term infants largely depend on the criteria that were used to define chorioamnionitis [2, 25-27]. Two broad disease groups have been identified to lead to preterm birth: inflammation and placental dysfunction resulting from vascular malfunction [13]. Since disorders of the latter group are also closely related to neonatal morbidity and mortality, assessment of chorioamnionitis as a risk factor for adverse outcome in very premature infants is hampered by the lack of a 'normal' control group.

\section{Chorioamnionitis and Respiratory Outcome}

The association between antenatal infection/inflammation and neonatal respiratory outcome has been extensively addressed in the last two decades with considerably variable results (table 1) [28-39]. Diverging defini- 
tions of inclusion criteria and major end points of the studies contribute to these variations [40].

Watterberg et al. [36] introduced the concept that exposure to intrauterine inflammation decreases the likelihood of respiratory distress syndrome (RDS) in premature infants but increases the risk for bronchopulmonary dysplasia (BPD). They demonstrated that histological chorioamnionitis led to adrenal stimulation, resulting in increased cortisol secretion and accelerated lung maturation [41]. In animal models, a maturational effect of prenatal inflammation on the lung has been demonstrated $[42,43]$. However, this effect has not been conferred by cortisol [44].

None of the infants in the initial Watterberg study [36] received antenatal steroids, which has meanwhile become standard care in cases of imminent preterm delivery [45]. This approach has been clearly linked with a decreased rate of RDS whereas the incidence of BPD has been shown unaffected [46-48]. The widespread use of antenatal steroids might partially explain why many later studies have shown either decreased or unaffected rates of RDS associated with histological chorioamnionitis but have not demonstrated a significant increase in BPD [2, $29,31,40,49,50]$.

In the late 1990s, an association between elevated amniotic fluid concentrations of proinflammatory cytokines and the development of BPD was demonstrated [51, 52]. These data suggested that fetal aspiration of cytokines contributes to a local pulmonary inflammation which makes the lung more susceptible for further injury from barotrauma or oxygen toxicity. In a retrospective study, amniotic fluid concentrations of matrix metalloproteinase- 8 and intraamniotic white blood cell counts were higher in infants born with a gestational age $\leq 32$ weeks who developed BPD without RDS compared to infants with BPD after RDS [53]. These data imply that intraamniotic inflammation is differentially associated with patterns of respiratory disease in these patients [53]. An increased influx of neutrophils, a higher expression of proinflammatory cytokines and an increased apoptosis of airway epithelial cells has been demonstrated in lung tissues of stillborn fetuses exposed to chorioamnionitis $[54,55]$.

Elevated IL-6 concentrations in cord blood predicted BPD in infants born $<34$ weeks of gestation better than elevated intraamniotic IL- 6 [37]. These data led to the conclusion that FIRS contained an even more pronounced risk for BPD than local intraamniotic inflammation. They were corroborated by studies linking umbilical cord vasculitis/funisitis, as histological counterparts of FIRS, with BPD [25, 32]. Other studies either did not find any association between chorioamnionitis with funisitis and the development of BPD $[29,49]$ or even an inverse association [30]. However, for the latter study, data of infants born in a single center over a 13 -year period were analyzed, an interval in which practice of neonatal care changed considerably [30].

In a case-control analysis nested in a cohort study, chorioamnionitis with fetal vasculitis was not a better predictor of BPD than isolated chorioamnionitis, which even was associated with a decreased rate of BPD in infants who were ventilated for less than 1 week [35]. However, in this study, chorioamnionitis was associated with an increased risk of BPD if mechanical ventilation had to be sustained for more than 7 days or infants experienced postnatal sepsis. This documented synergy underlines the complex interrelationship between prenatal inflammation and postnatal factors in the pathophysiology of this pulmonary disease (fig. 2) [56-58]. Advances in neonatal care which interfere with these modulating factors, like early administration of exogenous surfactant in combination with continuous positive airway pressure or noninvasive ventilation, will probably further mitigate the role of prenatal inflammation for the development of BPD [59-61].

Clinical chorioamnionitis has been identified as an independent risk factor for RDS in premature infants [62, 63], whereas histological chorioamnionitis seems to confer a beneficial effect on the incidence of RDS $[2,31,36$, $64,65]$. These data for histological chorioamnionitis are consistent with a maturational effect of prenatal exposure to inflammation on lung development shown in an animal model [43]. However, in this model, pulmonary maturation, induced by fetal inflammation, is associated with a significantly disturbed structural development of the lung [66].

Most recently, a cohort study including 301 infants with a gestational age $<32$ weeks has outlined another interesting effect of prenatal exposure to inflammation on respiratory physiology in infants at risk for RDS and BPD [67]. Histological chorioamnionitis deteriorated the response to exogenous surfactant associated with a longer need for mechanical ventilation in this study. This effect was more prominent in infants who also had histological signs of a fetal inflammatory response. In the group of infants treated with exogenous surfactant, those with a fetal inflammatory response developed BPD more frequently than those without signs of systemic inflammation. These observations underline that chorioamnionitis has synergistic effects with mechanical ventilation on the 
Fig. 2. Potential pathogenic sequences linking exposure of the fetus to prenatal inflammation with subsequent disturbed lung development [56] and cerebral injury [90] under further influence of postnatal factors.

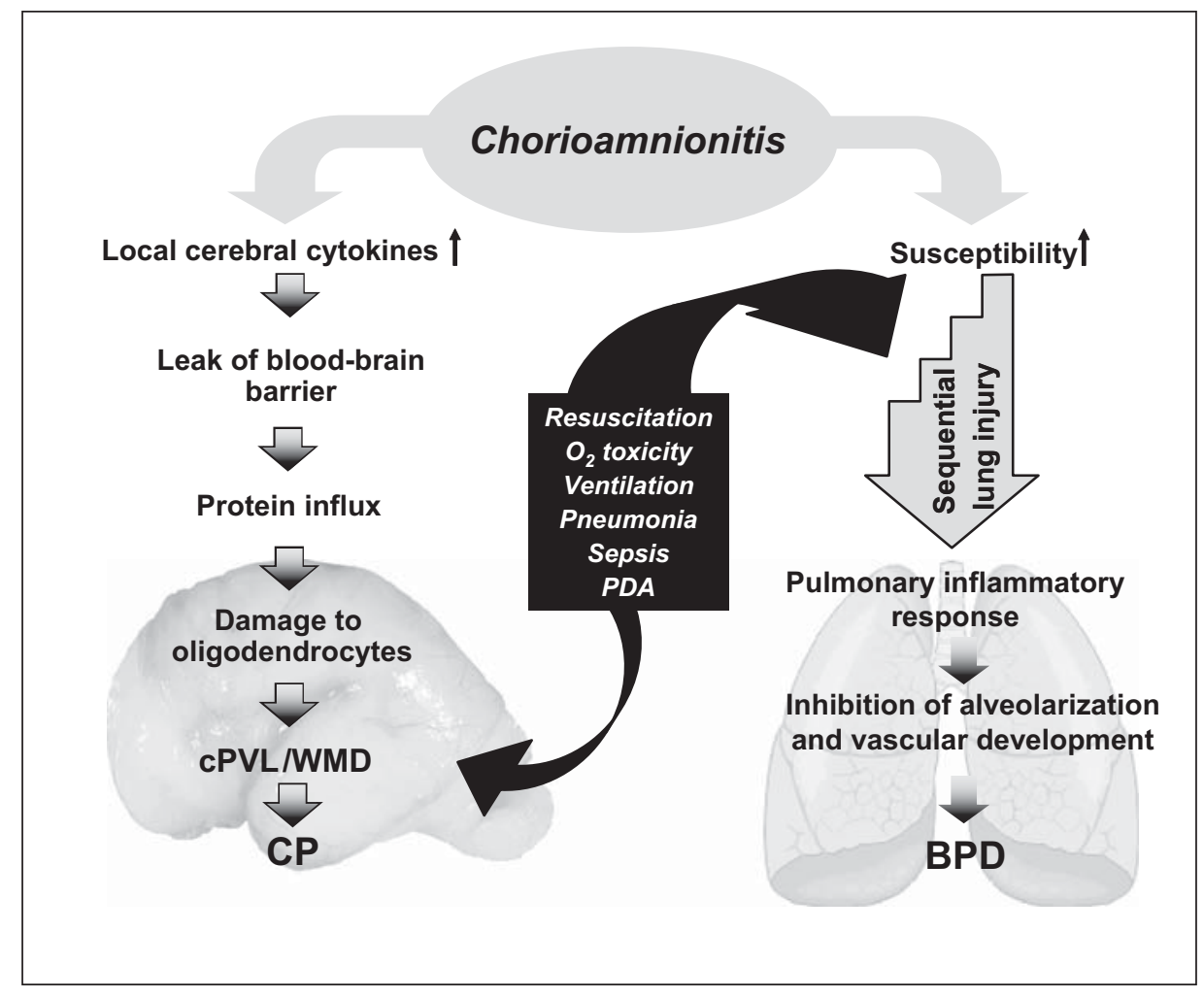

development of BPD [35]. Moreover, they allow the assumption that RDS after preterm birth resulting from chorioamnionitis may be distinct from that after preterm birth due to other reasons [68].

Thus, current evidence suggests that histological chorioamnionitis seems to decrease the risk of RDS in preterm infants through a maturational effect which in turn seems to contribute to a susceptibility of the lung for further postnatal injury (fig. 2) [40].

\section{Chorioamnionitis, Cystic Periventricular Leukomalacia, White Matter Disease and Cerebral Palsy}

Cerebral palsy (CP), a nonprogressive impairment of posture and motor function, is a major cause for physical disability in childhood [69]. In very premature infants, $\mathrm{CP}$ is clearly associated with cystic periventricular leukomalacia (PVL). Epidemiological studies addressing the risk for cystic PVL and later development of CP after perinatal infection/inflammation have come to variable results. Elevated cytokine levels in amniotic fluid [70,71] and in cord blood [72-74], indicating FIRS, were described to be related with CP in preterm and term neonates. However, in another study, neonatal blood cytokine levels in infants born before 32 weeks of gestation did only predict cystic PVL but not later CP [75]. Two systemic reviews of case-control and cohort studies have identified both clinical and histological chorioamnionitis to be associated with an increased risk of CP [76, 77]. The earlier meta-analysis also demonstrated an association of both entities with cystic PVL [76].

Other studies suggest that chorioamnionitis might be a risk factor for adverse neurological outcome in more mature infants. A case-control study including 109 children with spastic or dyskinetic CP identified clinical chorioamnionitis as a risk factor for $\mathrm{CP}$ in infants born after 36 weeks of gestation [78]. In a cohort of 483 singletons with a mean gestational age of 34.5 weeks (range 24-42) histological chorioamnionitis significantly increased the odds ratio for early abnormal brain sonography findings (increased periventricular echodensity or echolucency, severe intraventricular hemorrhage (IVH), ventriculomegaly) [7]. 
With advances in neonatal care the incidence of cystic PVL, diagnosed by cranial ultrasound, has decreased in extremely premature infants [79]. With the emergence of magnetic resonance imaging (MRI) noncystic diffuse or focal white matter disease (WMD) has been recognized as the most prevalent form of brain injury associated with adverse neurodevelopmental outcome in these infants [80]. Three recent prospective MRI studies failed to show an association between histological chorioamnionitis and microstructural changes of the brain at term [81-83]. It was neither associated with reduced brain volume at term [82] nor with abnormalities of metabolic or microstructural brain development earlier in postnatal life [83]. However, perinatal infection, reflected by maternal fever or proven neonatal sepsis at birth, predicted white matter abnormalities in a cohort of very premature infants [84].

Chau et al. [83] postulated that early postnatal infection and hypotension requiring intervention were more significant risk factors for early WMD than chorioamnionitis. Histological chorioamnionitis has been shown to increase the risk for arterial hypotension with the need for inotropic support on the first day of life [85]. Thus, chorioamnionitis still might contribute to the susceptibility of extremely premature infants to WMD-associated adverse neurological outcome [86]. However, arterial hypotension is inconsistently associated with cerebral white matter injury in very premature infants, largely depending on definitions applied for the two entities [8788].

Elevated proinflammatory cytokines in cord blood, reflecting FIRS, have been described to predict early cerebral lesions on MRI scans in premature infants, including WMD [89], whereas they did not predict WMD and adverse neurodevelopmental outcome by the age of 2 years in another prospective study [81].

Most recently, the large multicenter ELGAN (extremely low gestational age newborn) study supplied strong epidemiological evidence for a role of prenatal inflammation in the evolvement of WMD and CP in infants at highest risk for these outcomes [3]. Placental tissue for histological and microbiological assessment could be obtained from more than 1,200 infants born in 1 of 14 participating institutions before 28 weeks of gestation. 899 of them had a neurological examination by the corrected age of approximately 24 months. Histological chorioamnionitis as well as detection of microorganisms from placental tissue predicted ventriculomegaly, detected by cranial ultrasound and diparetic CP at follow-up. Moreover, recovery of microorganisms was also associated with cerebral white matter echolucencies in ultrasound scans [3].
Several findings from human studies and animal models support the concept that a fetal exposure to inflammation triggers a prolonged neuroinflammatory response of the central nervous system affecting the development of brain structure and function [90]. Such a sustained maturational disturbance of the fetal/neonatal brain plays an important role in the pathogenesis of both cystic PVL and WMD, summarized under the newly proposed term 'encephalopathy of prematurity' [91].

Postmortem immunohistochemical studies revealed a higher expression of TNF- $\alpha$, IL-1 $\beta$ and IL- 6 in brain sections of premature infants with PVL compared to brains with no signs of PVL $[92,93]$. The difference was particularly noticeable in the early phase of PVL and the expression of the proinflammatory mediators was significantly higher in those PVL infants who had suffered from clinical infection [93]. However, the higher expression of proinflammatory cytokines seems to reflect rather a local synthesis in the brain than the dissemination of the mediators via the bloodstream [93]. Accordingly, intraperitoneal endotoxin administration to pregnant rats induced cerebral production of TNF- $\alpha$ and IL-1 $\beta$ in their offspring [94]. Premature infants with WMD were shown to have higher concentrations of proinflammatory cytokines in their cerebrospinal fluid but there was no correlation between paired plasma and cerebrospinal fluid levels for any of the cytokines under investigation [95]. A genotype variation for IL-6, which enhances expression and activity of the cytokine, has been suggested a risk factor for WMD and severe IVH [96].

In an animal model, FIRS induced a local cerebral inflammatory response with disruption of the blood-brain barrier to proteins during a restricted period of fetal brain development, prior to or at the beginning of myelination [97-99]. A possible link between fetal inflammation and white matter injury might therefore be that both locally produced and systemic cytokines signal alterations of the tight junction structure of brain vessels leading to increased permeability for proteins which damage oligodendrocyte progenitors (fig. 2) [100]. Activated coagulation factors in premature infants with a systemic inflammatory response may also play a pathogenic role for cerebral WMD, not solely via vessel occlusion and ensuing brain ischemia but also by promoting inflammation [101].

To conclude, existing data suggest an association between chorioamnionitis (with and without signs of fetal response), cystic PVL and CP. The impact of chorioamnionitis on noncystic WMD identified in MRI is not as clear yet albeit it could be linked to sonographic signs of diffuse WMD in a recent multicenter study of extremely 
premature infants. Experimental data strongly support a role for prenatal inflammation in cerebral white matter injury (fig. 2).

\section{Intraventricular Hemorrhage of the Premature Infant}

The association of chorioamnionitis with IVH in premature infants has been addressed in several studies. Most of them suggested histological chorioamnionitis as a risk factor for IVH [7, 81, 102, 103], whereas others did not $[2,104]$. Increased concentrations of proinflammatory cytokines in umbilical cord blood as markers of a fetal inflammatory response did not consistently predict further development of IVH $[81,102,105]$.

\section{Chorioamnionitis, Neonatal Sepsis and Mortality}

In several cohort studies, histological chorioamnionitis was shown to be associated with an increased incidence of either culture-proven or clinically suspected sepsis in very preterm infants $[2,65,106]$, one study, however, failed to demonstrate such an association [103]. Neither of the studies could demonstrate an effect of histological chorioamnionitis on neonatal mortality $[2,65$, 103]. However, for preterm and term infants showing histological evidence of fetal involvement, a recent epidemiological study suggested an increased risk for both postnatal infection and increased mortality [25]. Another multicenter study with a large cohort of preterm infants linked clinical chorioamnionitis to neonatal sepsis but not death [27].

\section{Chorioamnionitis, Fetal Growth Restriction and Poor Neonatal Growth}

A large case-control study revealed an association between histological chorioamnionitis and fetal growth restriction, with the strongest association at earlier gestational ages [107]. The authors speculated that release of cytokines and other vasoactive substances in the setting of intrauterine infection might cause vasospasm and alter blood flow to the fetus. Other studies with far smaller sample sizes do not support this finding $[103,108]$. Recently, a significant association of histological chorioamnionitis with poor early postnatal growth could be demonstrated in a cohort of 256 preterm infants [108].

Chorioamnionitis and Neonatal Outcome

\section{Chorioamnionitis and Antenatal Steroids}

Current evidence supports a single course of antenatal steroids to accelerate fetal lung maturation in women at risk for preterm birth [45]. This treatment decreases neonatal mortality, the incidence of RDS, IVH, necrotizing enterocolitis and early-onset sepsis without significant maternal and fetal risks. It is therefore considered a standard treatment for preterm birth [45]. Repetitive courses of antenatal steroids are not justified because of their negative effects on fetal growth and head circumference [109].

There have been concerns that the risk of maternal or fetal infection might be increased with the administration of antenatal steroids in cases with clinical evidence of chorioamnionitis [110]. On the other hand, the combined effects of antenatal steroids and chorioamnionitis with and without fetal involvement on neonatal outcome are largely unknown [40].

According to a recent Cochrane analysis, there is no imminent risk of infection with the application of antenatal steroids for women with preterm premature rupture of membranes [45]. Three cohort studies suggest the same for infants with histological chorioamnionitis [4648]. Antenatal steroids were shown inconsistently associated with decreased mortality and lower incidence of RDS, IVH, WMD and CP in these infants [46, 48, 111]. However, none of the studies proved a synergistic effect of chorioamnionitis and antenatal steroids on any outcome measure. Remarkably, in two studies, antenatal steroids did not increase the risk for adverse neonatal events after clinical chorioamnionitis $[47,48]$.

Consequently, the administration of a single course of antenatal steroids seems to be safe in cases of obvious or suspected intrauterine inflammation. The efficacy of this approach has to be proven by randomized trials.

\section{Conclusions}

Current evidence underlines the role of chorioamnionitis as a major risk factor for spontaneous preterm birth, especially at earlier gestational ages. Therefore it clearly contributes to prematurity-associated mortality and morbidity. In the last decades there have been many attempts to assess a gestation-independent effect of chorioamnionitis on neonatal outcome with variable results. Shortcomings of many clinical studies have been their retrospective character and a lack of power to identify gestational age or other factors, which confound or mod-

Neonatology 2011;99:177-187 
ify detected associations between chorioamnionitis and outcome parameters. Besides, there is great variability in inclusion criteria between studies and in the way chorioamnionitis has been defined. The influence of chorioamnionitis on neonatal and long-term outcome has become less evident with advances in neonatal care. Clinical chorioamnionitis was shown to be associated with an increased risk for RDS whereas a short-term beneficial effect on incidence and severity of RDS could be demonstrated for histological chorioamnionitis. However, this maturational effect on the lung seems to be accompanied by a susceptibility of the organ for further postnatal in- jury. Existing data support a role of chorioamnionitis for cystic PVL, CP and IVH in preterm infants, but its association with noncystic WMD is not yet as clear. Prenatal inflammation/infection has been shown a risk factor for neonatal sepsis. A single course of antenatal steroids can be considered safe for mother and child in clinical as well as histological chorioamnionitis.

In the future, sufficiently powered studies of cohorts, which should be as homogeneous as possible or at least well-matched case-control studies, may add more evidence than currently available to enlighten the role of chorioamnionitis in neonatal outcome.

\section{References}

1 Hagberg H, Wennerholm UB, Savman K: Sequelae of chorioamnionitis. Curr Opin Infect Dis 2002;15:301-306.

-2 Andrews WW, Goldenberg RL, Faye-Petersen O, Cliver S, Goepfert AR, Hauth JC: The Alabama preterm birth study: polymorphonuclear and mononuclear cell placental infiltrations, other markers of inflammation, and outcomes in 23- to 32-week preterm newborn infants. Am J Obstet Gynecol 2006; 195:803-808

-3 Leviton A, Allred EN, Kuban KC, Hecht JL, Onderdonk AB, O'Shea TM, Paneth N: Microbiologic and histologic characteristics of the extremely preterm infant's placenta predict white matter damage and later cerebral palsy. The ELGAN study. Pediatr Res 2010; 67:95-101.

-4 Kusanovic JP, Romero R, Jodicke C, MazakiTovi S, Vaisbuch E, Erez O, Mittal P, Gotsch F, Chaiworapongsa T, Edwin SS, Pacora P, Hassan SS: Amniotic fluid soluble human leukocyte antigen-G in term and preterm parturition, and intra-amniotic infection/ inflammation. J Matern Fetal Neonatal Med 2009;22:1151-1166

-5 Yoon BH, Romero R, Kim CJ, Jun JK, Gomez R, Choi JH, Syn HC: Amniotic fluid interleukin-6: a sensitive test for antenatal diagnosis of acute inflammatory lesions of preterm placenta and prediction of perinatal morbidity. Am J Obstet Gynecol 1995;172:960-970.

6 Bracci R, Buonocore G: Chorioamnionitis: a risk factor for fetal and neonatal morbidity. Biol Neonate 2003;83:85-96.

7 De Felice C, Toti P, Laurini RN, Stumpo M, Picciolini E, Todros T, Tanganelli P, Buonocore G, Bracci R: Early neonatal brain injury in histologic chorioamnionitis. J Pediatr 2001;138:101-104.

$\checkmark 8$ Dammann O, Allred EN, Leviton A, ShenSchwarz S, Heller D, Genest DR, Collins $\mathrm{MH}$ : Fetal vasculitis in preterm newborns: interrelationships, modifiers, and antecedents. Placenta 2004;25:788-796.
-9 Van Hoeven KH, Anyaegbunam A, Hochster H, Whitty JE, Distant J, Crawford C, Factor SM: Clinical significance of increasing histologic severity of acute inflammation in the fetal membranes and umbilical cord. Pediatr Pathol Lab Med 1996;16:731-744.

10 Gotsch F, Romero R, Kusanovic JP, MazakiTovi S, Pineles BL, Erez O, Espinoza J, Hassan SS: The fetal inflammatory response syndrome. Clin Obstet Gynecol 2007;50: 652-683.

11 Gomez R, Romero R, Ghezzi F, Yoon BH, Mazor M, Berry SM: The fetal inflammatory response syndrome. Am J Obstet Gynecol 1998;179:194-202.

12 Muglia LJ, Katz M: The enigma of spontaneous preterm birth. N Engl J Med 2010;362: 529-535.

13 McElrath TF, Hecht JL, Dammann O, Boggess K, Onderdonk A, Markenson G, Harper M, Delpapa E, Allred EN, Leviton A: Pregnancy disorders that lead to delivery before the 28th week of gestation: an epidemiologic approach to classification. Am J Epidemiol 2008;168:980-989.

14 Onderdonk AB, Delaney ML, DuBois AM, Allred EN, Leviton A: Detection of bacteria in placental tissues obtained from extremely low gestational age neonates. Am J Obstet Gynecol 2008;198:110.e111-e117.

15 Dammann O, Leviton A, Allred EN: What explains away the increased risk of histological chorioamnionitis in African-American mothers of very-low-birthweight infants? Developmental epidemiology network investigators. Paediatr Perinat Epidemiol 2000;14:20-29.

16 Holzman C, Lin X, Senagore P, Chung H: Histologic chorioamnionitis and preterm delivery. Am J Epidemiol 2007;166:786-794.

17 Watts DH, Krohn MA, Hillier SL, Eschenbach DA: The association of occult amniotic fluid infection with gestational age and neonatal outcome among women in preterm labor. Obstet Gynecol 1992;79:351-357.
18 Onderdonk AB, Hecht JL, McElrath TF, Delaney ML, Allred EN, Leviton A: Colonization of second-trimester placenta parenchyma. Am J Obstet Gynecol 2008;199:52.e152.e10.

19 Hillier SL, Witkin SS, Krohn MA, Watts DH, Kiviat NB, Eschenbach DA: The relationship of amniotic fluid cytokines and preterm delivery, amniotic fluid infection, histologic chorioamnionitis, and chorioamnion infection. Obstet Gynecol 1993;81:941-948.

-20 Figueroa R, Garry D, Elimian A, Patel K, Sehgal PB, Tejani N: Evaluation of amniotic fluid cytokines in preterm labor and intact membranes. J Matern Fetal Neonatal Med 2005; 18:241-247.

-21 Yoon BH, Romero R, Moon JB, Shim SS, Kim M, Kim G, Jun JK: Clinical significance of intra-amniotic inflammation in patients with preterm labor and intact membranes. Am J Obstet Gynecol 2001;185:1130-1136.

-22 Kasper DC, Mechtler TP, Reischer GH, Witt A, Langgartner M, Pollak A, Herkner KR, Berger A: The bacterial load of Ureaplasma parvum in amniotic fluid is correlated with an increased intrauterine inflammatory response. Diagn Microbiol Infect Dis 2010;67: 117-121.

23 Houben ML, Nikkels PGJ, van Bleek GM, Visser GHA, Rovers MM, Kessel H, de Waal WJ, Schuijff L, Evers A, Kimpen JLL, Bont L: The association between intrauterine inflammation and spontaneous vaginal delivery at term: a cross-sectional study. PLoS ONE 2009;4:e6572.

-24 Goldenberg RL, Hauth JC, Andrews WW: Intrauterine infection and preterm delivery. N Engl J Med 2000;342:1500-1507.

25 Lau J, Magee F, Qiu Z, Hoube J, Von Dadelszen P, Lee SK: Chorioamnionitis with a fetal inflammatory response is associated with higher neonatal mortality, morbidity, and resource use than chorioamnionitis displaying a maternal inflammatory response only. Am J Obstet Gynecol 2005;193:708-713. 
-26 Ramsey PS, Lieman JM, Brumfield CG, Carlo W: Chorioamnionitis increases neonatal morbidity in pregnancies complicated by preterm premature rupture of membranes. Am J Obstet Gynecol 2005;192:1162-1166.

-27 Soraisham AS, Singhal N, McMillan DD, Sauve RS, Lee SK: A multicenter study on the clinical outcome of chorioamnionitis in preterm infants. Am J Obstet Gynecol 2009;200: 372.e371-e376.

-28 Kaukola T, Tuimala J, Herva R, Kingsmore S, Hallman M: Cord immunoproteins as predictors of respiratory outcome in preterm infants. Am J Obstet Gynecol 2009;200:100. e101-e108.

-29 Kent A, Dahlstrom JE: Chorioamnionitis/ funisitis and the development of bronchopulmonary dysplasia. J Paediatr Child Health 2004;40:356-359.

>30 Lahra MM, Beeby PJ, Jeffery HE: Intrauterine inflammation, neonatal sepsis, and chronic lung disease: a 13-year hospital cohort study. Pediatrics 2009;123:1314-1319.

-31 Lahra MM, Beeby PJ, Jeffery HE: Maternal versus fetal inflammation and respiratory distress syndrome: a 10-year hospital cohort study. Arch Dis Child Fetal Neonatal Ed 2009;94:F13-F16

-32 Matsuda T, Nakajima T, Hattori S, Hanatani K, Fukazawa Y, Kobayashi K, Fujimoto S: Necrotizing funisitis: clinical significance and association with chronic lung disease in premature infants. Am J Obstet Gynecol 1997; 177:1402-1407.

33 Mittendorf R, Covert R, Montag AG, elMasri W, Muraskas J, Lee KS, Pryde PG: Special relationships between fetal inflammatory response syndrome and bronchopulmonary dysplasia in neonates. J Perinat Med 2005;33: 428-434.

$\checkmark 34$ Redline RW, Wilson-Costello D, Hack M: Placental and other perinatal risk factors for chronic lung disease in very low birth weight infants. Pediatr Res 2002;52:713-719.

- 35 Van Marter LJ, Dammann O, Allred EN, Leviton A, Pagano M, Moore M, Martin C: Chorioamnionitis, mechanical ventilation, and postnatal sepsis as modulators of chronic lung disease in preterm infants. J Pediatr 2002;140:171-176.

>36 Watterberg KL, Demers LM, Scott SM, Murphy S: Chorioamnionitis and early lung inflammation in infants in whom bronchopulmonary dysplasia develops. Pediatrics 1996; 97:210-215.

\37 Yoon BH, Romero R, Kim KS, Park JS, Ki SH, Kim BI, Jun JK: A systemic fetal inflammatory response and the development of bronchopulmonary dysplasia. Am J Obstet Gynecol 1999;181:773-779.

-38 Zanardo V, Vedovato S, Suppiej A, Trevisanuto D, Migliore M, Di Venosa B, Chiarelli S: Histological inflammatory responses in the placenta and early neonatal brain injury. Pediatr Dev Pathol 2008;11:350-354.
39 Ogunyemi D, Murillo M, Jackson U, Hunter $\mathrm{N}$, Alperson B: The relationship between placental histopathology findings and perinata outcome in preterm infants. J Matern Fetal Neonatal Med 2003;13:102-109.

40 Been JV, Zimmermann LJ: Histological chorioamnionitis and respiratory outcome in preterm infants. Arch Dis Child Fetal Neonatal Ed 2009;94:F218-F225.

41 Watterberg KL, Scott SM, Naeye RL: Chorioamnionitis, cortisol, and acute lung disease in very low birth weight infants. Pediatrics 1997;99:E6.

42 Kramer BW: Antenatal inflammation and lung injury: prenatal origin of neonatal disease. J Perinatol 2008;28(suppl 1):S21-S27.

43 Kramer BW, Kallapur S, Newnham J, Jobe $\mathrm{AH}$ : Prenatal inflammation and lung development. Semin Fetal Neonatal Med 2009;14 $2-7$.

44 Jobe AH, Newnham JP, Willet KE, Moss TJ, Gore Ervin M, Padbury JF, Sly P, Ikegami M Endotoxin-induced lung maturation in preterm lambs is not mediated by cortisol. Am Respir Crit Care Med 2000;162:1656-1661.

45 Roberts D, Dalziel S: Antenatal corticosteroids for accelerating fetal lung maturation for women at risk of preterm birth. Cochrane Database Syst Rev 2006;3:CD004454.

46 Elimian A, Verma U, Beneck D, Cipriano R, Visintainer P, Tejani N: Histologic chorioamnionitis, antenatal steroids, and perinatal outcomes. Obstet Gynecol 2000;96:333-336.

47 Goldenberg RL, Andrews WW, Faye-Petersen OM, Cliver SP, Goepfert AR, Hauth JC: The Alabama Preterm Birth Study: corticosteroids and neonatal outcomes in 23- to 32 week newborns with various markers of intrauterine infection. Am J Obstet Gyneco 2006;195:1020-1024.

48 Been JV, Rours IG, Kornelisse RF, Lima Passos V, Kramer BW, Schneider TA, de Krijger RR, Zimmermann LJ: Histologic chorioamnionitis, fetal involvement, and antenatal steroids: effects on neonatal outcome in preterm infants. Am J Obstet Gynecol 2009;201: 587.e581-e588.

49 Richardson BS, Wakim E, daSilva O, Walton J: Preterm histologic chorioamnionitis: impact on cord gas and $\mathrm{pH}$ values and neonatal outcome. Am J Obstet Gynecol 2006;195: 1357-1365.

50 Laughon M, Allred EN, Bose C, O’Shea TM, Van Marter LJ, Ehrenkranz RA, Leviton A: Patterns of respiratory disease during the first 2 postnatal weeks in extremely premature infants. Pediatrics 2009;123:1124-1131.

51 Yoon BH, Romero R, Jun JK, Park KH, Park JD, Ghezzi F, Kim BI: Amniotic fluid cytokines (interleukin-6, tumor necrosis factor$\alpha$, interleukin- $1 \beta$, and interleukin-8) and the risk for the development of bronchopulmonary dysplasia. Am J Obstet Gynecol 1997; 177:825-830.
52 Ghezzi F, Gomez R, Romero R, Yoon BH, Edwin SS, David C, Janisse J, Mazor M: Elevated interleukin- 8 concentrations in amniotic fluid of mothers whose neonates subsequently develop bronchopulmonary dysplasia. Eur J Obstet Gynecol Reprod Biol 1998; 78:5-10.

53 Lee J, Oh KJ, Yang HJ, Park JS, Romero R, Yoon BH: The importance of intra-amniotic inflammation in the subsequent development of atypical chronic lung disease. J Matern Fetal Neonatal Med 2009;22:917-923.

54 May M, Marx A, Seidenspinner S, Speer CP: Apoptosis and proliferation in lungs of human fetuses exposed to chorioamnionitis. Histopathology 2004;45:283-290.

55 Schmidt B, Cao L, Mackensen-Haen S, Kendziorra H, Klingel K, Speer CP: Chorioamnionitis and inflammation of the fetal lung. Am J Obstet Gynecol 2001;185:173-177.

56 Speer CP: Inflammation and bronchopulmonary dysplasia: a continuing story. Semin Fetal Neonatal Med 2006;11:354-362.

57 Speer CP: Chorioamnionitis, postnatal factors and proinflammatory response in the pathogenetic sequence of bronchopulmonary dysplasia. Neonatology 2009;95:353-361.

58 Groneck P, Gotze-Speer B, Oppermann M, Eiffert H, Speer CP: Association of pulmonary inflammation and increased microvascular permeability during the development of bronchopulmonary dysplasia: a sequential analysis of inflammatory mediators in respiratory fluids of high-risk preterm neonates. Pediatrics 1994;93:712-718.

59 Ramanathan R: Optimal ventilatory strategies and surfactant to protect the preterm lungs. Neonatology 2008;93:302-308.

60 Bohlin K, Jonsson B, Gustafsson AS, Blennow $\mathrm{M}$ : Continuous positive airway pressure and surfactant. Neonatology 2008;93:309315 .

61 Thomas W, Speer CP: Nonventilatory strategies for prevention and treatment of bronchopulmonary dysplasia - what is the evidence? Neonatology 2008;94:150-159.

-62 Alexander JM, Gilstrap LC, Cox SM, McIntire DM, Leveno KJ: Clinical chorioamnionitis and the prognosis for very low birth weight infants. Obstet Gynecol 1998;91:725729 .

63 Morales WJ, Washington SR 3rd, Lazar AJ: The effect of chorioamnionitis on perinatal outcome in preterm gestation. J Perinatol 1987;7:105-110

64 Lee J, Seong HS, Kim BJ, Jun JK, Romero R, Yoon $\mathrm{BH}$ : Evidence to support that spontaneous preterm labor is adaptive in nature: neonatal RDS is more common in 'indicated' than in 'spontaneous' preterm birth. J Perinat Med 2009;37:53-58.

65 Dempsey E, Chen MF, Kokottis T, Vallerand D, Usher R: Outcome of neonates less than 30 weeks' gestation with histologic chorioamnionitis. Am J Perinatol 2005;22:155-159. 
-66 Kramer BW, Ladenburger A, Kunzmann S, Speer CP, Been JV, van Iwaarden JF, Zimmermann LJ, Gantert M, Garnier Y: Intravenous lipopolysaccharide-induced pulmonary maturation and structural changes in fetal sheep. Am J Obstet Gynecol 2009;200: 195.e1-195.e10.

67 Been JV, Rours IG, Kornelisse RF, Jonkers F, de Krijger RR, Zimmermann LJ: Chorioamnionitis alters the response to surfactant in preterm infants. J Pediatr 2010;156:10-15.

68 Jobe AH, Kallapur SG: Chorioamnionitis, surfactant, and lung disease in very low birth weight infants. J Pediatr 2010;156:3-4.

69 Bashiri A, Burstein E, Mazor M: Cerebral palsy and fetal inflammatory response syndrome: a review. J Perinat Med 2006;34:5-12.

70 Yoon BH, Romero R, Park JS, Kim CJ, Kim $\mathrm{SH}$, Choi JH, Han TR: Fetal exposure to an intra-amniotic inflammation and the development of cerebral palsy at the age of three years. Am J Obstet Gynecol 2000;182:675681.

71 Yoon BH, Jun JK, Romero R, Park KH, Gomez R, Choi JH, Kim IO: Amniotic fluid inflammatory cytokines (interleukin-6, interleukin-1 $\beta$, and tumor necrosis factor- $\alpha$ ), neonatal brain white matter lesions, and cerebral palsy. Am J Obstet Gynecol 1997;177: 19-26.

-72 Minagawa K, Tsuji Y, Ueda H, Koyama K, Tanizawa $\mathrm{K}$, Okamura $\mathrm{H}$, Hashimoto-Tamaoki $\mathrm{T}$ : Possible correlation between high levels of IL-18 in the cord blood of pre-term infants and neonatal development of periventricular leukomalacia and cerebral palsy. Cytokine 2002;17:164-170.

73 Nelson KB, Dambrosia JM, Grether JK, Phillips TM: Neonatal cytokines and coagulation factors in children with cerebral palsy. Ann Neurol 1998;44:665-675.

74 Hansen-Pupp I, Hallin AL, Hellstrom-Westas L, Cilio C, Berg AC, Stjernqvist K, Fellman V, Ley D: Inflammation at birth is associated with subnormal development in very preterm infants. Pediatr Res 2008;64: 183-188.

75 Nelson KB, Grether JK, Dambrosia JM, Walsh E, Kohler S, Satyanarayana G, Nelson PG, Dickens BF, Phillips TM: Neonatal cytokines and cerebral palsy in very preterm infants. Pediatr Res 2003;53:600-607.

76 Wu YW: Systematic review of chorioamnionitis and cerebral palsy. Ment Retard Dev Disabil Res Rev 2002;8:25-29.

77 Shatrov JG, Birch SC, Lam LT, Quinlivan JA, McIntyre S, Mendz G: Chorioamnionitis and cerebral palsy. Obstet Gynecol 2010;116: 387-392.

78 Wu YW, Escobar GJ, Grether JK, Croen LA, Greene JD, Newman TB: Chorioamnionitis and cerebral palsy in term and near-term infants. JAMA 2003;290:2677-2684.
79 Hamrick SE, Miller SP, Leonard C, Glidden DV, Goldstein R, Ramaswamy V, Piecuch R, Ferriero DM: Trends in severe brain injury and neurodevelopmental outcome in premature newborn infants: the role of cystic periventricular leukomalacia. J Pediatr 2004; 145:593-599.

80 Miller SP, Ferriero DM, Leonard C, Piecuch R, Glidden DV, Partridge JC, Perez M, Mukherjee P, Vigneron DB, Barkovich AJ Early brain injury in premature newborns detected with magnetic resonance imaging is associated with adverse early neurodevelopmental outcome. J Pediatr 2005;147:609-616.

81 Kaukola T, Herva R, Perhomaa M, Paakko E, Kingsmore S, Vainionpaa L, Hallman M Population cohort associating chorioamnionitis, cord inflammatory cytokines and neurologic outcome in very preterm, extremely low birth weight infants. Pediatr Res 2006; 59:478-483.

82 Reiman M, Kujari H, Maunu J, Parkkola R, Rikalainen H, Lapinleimu H, Lehtonen L, Haataja L: Does placental inflammation relate to brain lesions and volume in preterm infants? J Pediatr 2008;152:642-647, 647. e641-e642.

83 Chau V, Poskitt KJ, McFadden DE, BowenRoberts T, Synnes A, Brant R, Sargent MA, Soulikias W, Miller SP: Effect of chorioamnionitis on brain development and injury in premature newborns. Ann Neurol 2009;66: 155-164.

84 Inder TE, Wells SJ, Mogridge NB, Spencer C, Volpe JJ: Defining the nature of the cerebral abnormalities in the premature infant: a qualitative magnetic resonance imaging study. J Pediatr 2003;143:171-179.

85 Lee SY, Ng DK, Fung GP, Chow CB, Shek CC, Tang PM, Shiu YK, Yu VY: Chorioamnionitis with or without funisitis increases the risk of hypotension in very low birthweight infants on the first postnatal day but not later. Arch Dis Child Fetal Neonatal Ed 2006; 91:F346-F348.

86 De Vries LS: Effect of chorioamnionitis on brain development and injury in premature newborns. Ann Neurol 2009;66:127-129.

87 Dammann O, Allred EN, Kuban KC, Van Marter LJ, Pagano M, Sanocka U, Leviton A: Systemic hypotension and white-matter damage in preterm infants. Dev Med Child Neurol 2002;44:82-90.

88 Limperopoulos C, Bassan H, Kalish LA, Ringer SA, Eichenwald EC, Walter G, Moore M, Vanasse M, DiSalvo DN, Soul JS, Volpe JJ, du Plessis AJ: Current definitions of hypotension do not predict abnormal cranial ultrasound findings in preterm infants. Pediatrics 2007; 120:966-977.

89 Duggan PJ, Maalouf EF, Watts TL, Sullivan MH, Counsell SJ, Allsop J, Al-Nakib L, Rutherford MA, Battin M, Roberts I, Edwards AD: Intrauterine T-cell activation and increased proinflammatory cytokine concentrations in preterm infants with cerebral lesions. Lancet 2001;358:1699-1700.
90 Malaeb S, Dammann O: Fetal inflammatory response and brain injury in the preterm newborn. J Child Neurol 2009;24: 1119-1126.

$\$ 91$ Volpe JJ: Brain injury in premature infants: a complex amalgam of destructive and developmental disturbances. Lancet Neurol 2009;8:110-124.

-92 Yoon BH, Romero R, Kim CJ, Koo JN, Choe G, Syn HC, Chi JG: High expression of tumor necrosis factor- $\alpha$ and interleukin- 6 in periventricular leukomalacia. Am J Obstet Gynecol 1997;177:406-411.

$\$ 93$ Kadhim H, Tabarki B, Verellen G, De Prez C, Rona AM, Sebire G: Inflammatory cytokines in the pathogenesis of periventricular leukomalacia. Neurology 2001;56:12781284.

94 Cai Z, Pan ZL, Pang Y, Evans OB, Rhodes PG: Cytokine induction in fetal rat brains and brain injury in neonatal rats after maternal lipopolysaccharide administration. Pediatr Res 2000;47:64-72.

$\checkmark 95$ Ellison VJ, Mocatta TJ, Winterbourn CC, Darlow BA, Volpe JJ, Inder TE: The relationship of CSF and plasma cytokine levels to cerebral white matter injury in the premature newborn. Pediatr Res 2005;57:282-286.

$\$ 96$ Harding DR, Dhamrait S, Whitelaw A, Humphries SE, Marlow N, Montgomery HE: Does interleukin- 6 genotype influence cerebral injury or developmental progress after preterm birth? Pediatrics 2004;114: 941-947.

$\checkmark 97$ Stolp HB, Dziegielewska KM, Ek CJ, Habgood MD, Lane MA, Potter AM, Saunders NR: Breakdown of the blood-brain barrier to proteins in white matter of the developing brain following systemic inflammation. Cell Tissue Res 2005;320:369-378.

$\checkmark 98$ Stolp HB, Dziegielewska KM, Ek CJ, Potter AM, Saunders NR: Long-term changes in blood-brain barrier permeability and white matter following prolonged systemic inflammation in early development in the rat. Eur J Neurosci 2005;22:2805-2816.

$\checkmark 99$ Stolp HB, Ek CJ, Johansson PA, Dziegielewska KM, Bethge N, Wheaton BJ, Potter AM, Saunders NR: Factors involved in inflammation-induced developmental white matter damage. Neurosci Lett 2009; 451:232-236.

100 Stolp HB, Dziegielewska KM: Role of developmental inflammation and blood-brain barrier dysfunction in neurodevelopmental and neurodegenerative diseases. Neuropathol Appl Neurobiol 2009;35:132-146.

101 Leviton A, Dammann O: Coagulation, inflammation, and the risk of neonatal white matter damage. Pediatr Res 2004;55:541545.

102 Tauscher MK, Berg D, Brockmann M, Seidenspinner S, Speer CP, Groneck P: Association of histologic chorioamnionitis, increased levels of cord blood cytokines, and intracerebral hemorrhage in preterm neonates. Biol Neonate 2003;83:166-170. 
-103 Dexter SC, Pinar H, Malee MP, Hogan J, Carpenter MW, Vohr BR: Outcome of very low birth weight infants with histopathologic chorioamnionitis. Obstet Gynecol 2000;96:172-177.

104 Sarkar S, Kaplan C, Wiswell TE, Spitzer AR: Histological chorioamnionitis and the risk of early intraventricular hemorrhage in infants born $<$ or $=28$ weeks' gestation. J Perinatol 2005;25:749-752.

-105 Heep A, Behrendt D, Nitsch P, Fimmers R, Bartmann P, Dembinski J: Increased serum levels of interleukin- 6 are associated with severe intraventricular haemorrhage in extremely premature infants. Arch Dis Child Fetal Neonatal Ed 2003;88:F501-F504.
106 Baud O, Emilie D, Pelletier E, Lacaze-Masmonteil T, Zupan V, Fernandez H, Dehan M, Frydman R, Ville Y: Amniotic fluid concentrations of interleukin-1 $\beta$, interleukin- 6 and TNF- $\alpha$ in chorioamnionitis before 32 weeks of gestation: histological associations and neonatal outcome. $\mathrm{Br} \mathrm{J}$ Obstet Gynaecol 1999;106:72-77.

107 Williams MC, O’Brien WF, Nelson RN, Spellacy WN: Histologic chorioamnionitis is associated with fetal growth restriction in term and preterm infants. Am J Obstet Gynecol 2000;183:1094-1099.

108 Mestan K, Yu Y, Matoba N, Cerda S, Dem min B, Pearson C, Ortiz K, Wang X: Placental inflammatory response is associated with poor neonatal growth: preterm birth cohort study. Pediatrics 2010;125:e891e898.
109 Murphy KE, Hannah ME, Willan AR, Hewson SA, Ohlsson A, Kelly EN, Matthews SG, Saigal S, Asztalos E, Ross S, Delisle MF, Amankwah K, Guselle P, Gafni A, Lee SK, Armson BA: Multiple courses of antenatal corticosteroids for preterm birth (MACS): a randomised controlled trial. Lancet 2008;372:2143-2151.

110 NIH consensus development panel on the effect of corticosteroids for fetal maturation on perinatal outcomes. Effect of corticosteroids for fetal maturation on perinatal outcomes. JAMA 1995;273:413-418.

111 Kent A, Lomas F, Hurrion E, Dahlstrom JE: Antenatal steroids may reduce adverse neurological outcome following chorioamnionitis: neurodevelopmental outcome and chorioamnionitis in premature infants. J Paediatr Child Health 2005;41:186-190. 